\title{
Evaluation of the Use of Grid Platforms to Minimize Shading Impacts to Seagrasses
}

\section{INTRODUCTION}

Background. Seagrasses are widely recognized as one of the most productive and valuable habitats in shallow marine environments. In addition to providing habitat and nursery grounds for many fishery species of commercial and recreational importance, seagrasses also filter the water column and stabilize sediments. The amount of available light is one of the most important factors affecting the survival, growth, and depth distribution of seagrasses (Bulthuis 1983, Dennison 1987, Abal et al. 1994, Kenworthy and Fonseca 1996).

Although the seagrass response to light has been reported in numerous studies (Bulthuis 1983, Neverauskas 1988, Abal et al. 1994, Gordon et al. 1994, Czerny and Dunton 1995, Fitzpatrick and Kirkman 1995), published reports which document the effects of shading by dock structures are rare. Due to the limited data available, there has been a lack of consistency in the development and application of regulatory policy to address dock shading impacts. Guidelines concerning the placement, height, width, and type of construction for docks and piers over seagrasses often address light availability to the underlying seagrass beds by setting minimum height and maximum width of the dock, spacing of the decking, etc. These guidelines have often been based on very limited surveys or best professional judgment and have been criticized for a lack of supporting data to evaluate their effectiveness.

Due to continuing rapid development in the coastal zone, there is a concern that the proliferation of dock structures will negatively impact seagrass meadows. Loss of seagrass cover in areas under and adjacent to docks may result from shading, piling installation, and boat traffic (i.e., prop scarring). The use of high-pressure jet pumps during piling installation often results in large bare clearings around individual pilings, which may persist for years following construction. ${ }^{1}$ Although the area of seagrass loss associated with any individual dock is relatively small, cumulative impacts and fragmentation of seagrass beds may be significant along highly developed shorelines. In Palm Beach County, Florida, more than 50 acres of seagrasses are estimated to have been negatively impacted due to single-family dock structures (Smith and Mezich 1999). With seagrass populations in decline in many areas, coastal resource managers are interested in the development of consistent, defensible guidelines to reduce additional dock-associated impacts to an already stressed resource. Until recently, quantitative data to support the development of regulatory guidelines concerning the placement of docks over seagrass beds have been lacking (see Loflin (1995), Burdick and Short (1999), Shafer (1999)).

Guideline Development. In Massachusetts, studies on dock impacts to seagrasses have shown the three most important factors affecting seagrass growth are dock height, orientation, and width.

1 Personal observation, 2001, Deborah Shafer, Research Marine Biologist, U.S. Army Engineer Research and Development Center, Vicksburg, MS. 
However, due to differences in tidal range, latitude, water quality, and the light requirements of different seagrass species, specific dock guidelines developed in one region may not be appropriate elsewhere.

In July 1998, through the Wetlands Regulatory Assistance Program (WRAP), the Regulatory Office of the U.S. Army Engineer District, Jacksonville, invited representatives of the Engineer Research and Development Center, National Marine Fisheries Service, U.S. Fish and Wildlife Service, Florida Department of Environmental Protection, and the private sector marine construction industry to attend a workshop to develop guidelines for the design and construction of docks in seagrasses. These guidelines were intended to minimize the loss of seagrass associated with docks in seagrass beds. Appendix A summarizes recommendations for construction and design of docks over seagrasses.

Study Objectives. Since light is one of the most important factors affecting seagrass survival and growth, the use of alternative construction techniques to increase the amount of light received by the seagrasses below has been suggested as a viable mechanism to reduce loss of seagrass due to dock shading impacts.

A preliminary investigation of alternative decking materials compared acrylic, acrylic with matting, lexan, aluminum grating and fiberglass grating. On the basis of this study, the Dade County (Florida) Department of Environmental Resources Management (DERM) concluded that only the fiberglass grating material showed promise (Molnar, Markley, and Mayo 1989). DERM recommended that additional studies involving dock construction with fiberglass grating be conducted (Molnar, Markley, and Mayo 1989).

The current version of the guidelines for construction of docks and piers requires that terminal platforms that exceed $120 \mathrm{ft}^{2}$ be constructed of fiberglass grating if they are built over seagrasses (Appendix A). The present study was designed to evaluate the effectiveness of the fiberglass grating through the construction and monitoring of two experimental platforms over seagrass beds in St. Andrew Bay, FL.

The major objectives of this study are:

- Compare the light environment under the experimental platform to nearby unshaded control sites.

- Measure changes in seagrass density and percent cover under the experimental platform over time (pre- and post-construction monitoring).

- Evaluate a construction technique designed to reduce seagrass loss associated with piling installation. 


\section{METHODS}

Platform Construction. Two experimental platforms were constructed in April 1999 within the St. Andrew State Park in Panama City Beach, FL (Figure 1). Appropriate permits were obtained prior to platform construction. This site was chosen because of the presence of continuous beds of the seagrass Thalassia testudinum in a location that offered easy access for monitoring and data collection. Water depths at the site were approximately $3.5 \mathrm{ft}$ MHW. Dimensions of each platform were

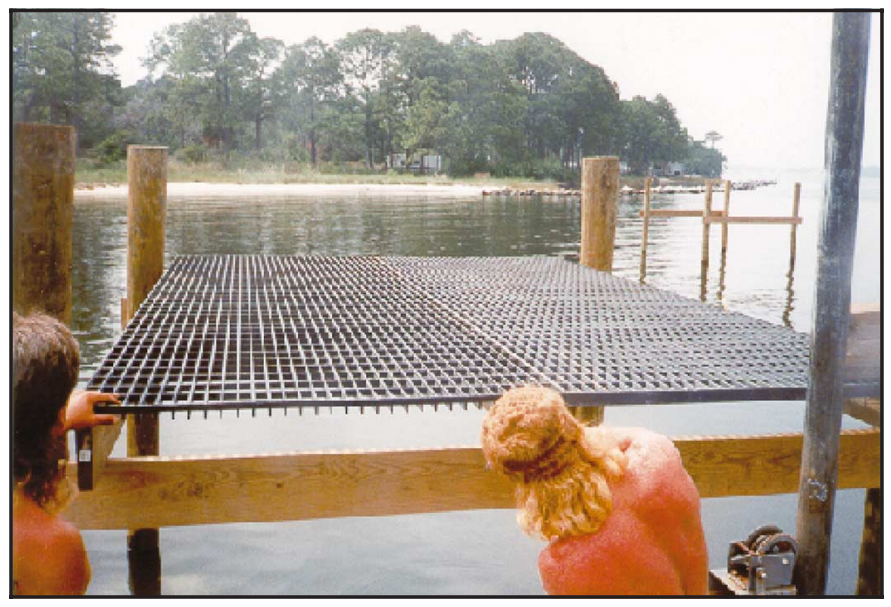

Figure 1. Experimental grid platform 8 by $12 \mathrm{ft}$ with the long axis oriented in an east-west direction. The two platforms were constructed at differing heights (4 ft and $5 \mathrm{ft}$ above MHW) to compare the effects of dock height.

Based on the recommendations of dock construction guidelines used for Ono Island, AL, the following technique was adopted for piling installation during this study. All equipment was transported to the site on a shallow-draft barge. A pilot hole was created by using a 3-in. centrifugal pump run at low rpm and short, quick insertion of a hand-held 1-1/2-in.-diameter lance. The pile was sharpened to a point with a chain saw and the point then placed in the pilot hole. The pile was then driven to grade with a 350-lb drop hammer. Sediments that accumulated on top of the adjacent seagrasses were removed to prevent burial of the plants.

Immediately following piling installation, the distances between the piling and the nearest edge of the seagrasses were measured along the north, south, east, and west axis of each piling. After two growing seasons, these distances were re-measured in August 2000 to determine the extent of seagrass regrowth into the bare areas produced during piling installation.

\section{Data Collection}

In situ irradiance. Four spherical quantum light sensors (LI 193SA, LICOR, Inc.) were used to record simultaneous light data (LI 1000 data logger, LICOR, Inc.) in the air and underwater in shaded and unshaded plots. Shaded sensors were placed under the center of each platform. Underwater sensors were placed near the top of the seagrass canopy as described in Dunton (1994).

Continuous light data were recorded for a total of 26 days during the 1999 growing season, and 37 days during the 2000 growing season (Table 1). The recorded light integration period was set at $15 \mathrm{~min}$.

The percent surface irradiance for each underwater record was determined by comparison with the surface-mounted sensor at each dock. Mean daily percent surface irradiance (SI) values were calculated by averaging these values over a 10-hr period from 8:00 a.m. to 6:00 p.m. The relative

\begin{tabular}{|l|l|}
\hline \multicolumn{2}{|l|}{$\begin{array}{l}\text { Table 1 } \\
\text { Light Data Collection Periods }\end{array}$} \\
\hline From & To \\
\hline May 13, 2000 & May 25, 2000 \\
\hline June 19, 2000 & June 29, 2000 \\
\hline July 25, 2000 & August 9, 2000 \\
\hline May 4, 1999 & May 16, 1999 \\
\hline June 3, 1999 & June 17, 1999 \\
\hline
\end{tabular}


amount of light reduction due to shading by the platform was also calculated for each using the difference between shaded and control stations.

Seagrass characteristics. Good water clarity at the site permitted estimates of seagrass percent cover and density using nondestructive visual sampling techniques. An initial site survey was performed to determine baseline conditions prior to platform construction; seagrass percent cover and shoot density were measured again in May and August 2000. Due to the large storage capacity of below-ground rhizomes of Thalassia testudinum, declines in shoot density may not become apparent until several months after the initiation of shading (Czerny and Dunton 1995). Therefore, estimates of shoot density and percent cover presented in this report were made at the beginning and end of the second growing season following platform construction. Mean seagrass percent cover was estimated using a series of twelve $2.7-\mathrm{ft}^{2}\left(0.25-\mathrm{m}^{2}\right)$ plots. Mean shoot density was estimated from a series of ten $0.4-\mathrm{ft}^{2}\left(400-\mathrm{cm}^{2}\right)$ plots beneath each platform. Mean shoot density and percent cover measured directly beneath each platform were compared with those of an unshaded control site at the same depth centered between the two platforms at a distance of approximately $50 \mathrm{ft}$.

\section{Statistical Analysis}

Changes in seagrass density and percent cover were analyzed with a two-factor analysis of variance (ANOVA) using season (spring and fall) and shade (5-ft platform, 4-ft platform, and control) as factors. If a significant interaction effect between season and shade was observed, a separate one-way ANOVA on shade was run for each season. This was necessary since it is not valid to interpret main effects in the presence of a significant interaction (Zar 1996). If a significant effect due to shade was observed, Tukey's multiple comparison was used to compare the various levels of shade. Data were tested for normality and homogeneity of variances prior to analysis.

RESULTS: Numerous studies have shown that seagrass biomass and density are decreased at lower light levels (Bulthuis 1983; Neveraskas 1988; Czerny and Dunton 1995). In this study, observed declines in seagrass density and percent cover were related to light reductions produced by dock structures.

Mean shoot density at unshaded sites was higher in August than in April (Figure 2); values ranged from approximately 454 shoots $/ \mathrm{m}^{-2}$ to 789 shoots $/ \mathrm{m}^{-2}$. Mean shoot densities beneath the experimental platforms ranged from 377 shoots $/ \mathrm{m}^{-2}$ to 454 shoots $/ \mathrm{m}^{-2}$. A significant effect due to shade was observed for both May $(\mathrm{p}=0.001)$ and August $(\mathrm{p}<0.001)$ sampling dates. In May 2000, seagrass densities beneath the 5-ft and 4-ft MHW platforms were 65 percent and 68 percent of the unshaded control, respectively. In August 2000, seagrass densities beneath the 5-ft and 4-ft MHW platforms were 52 percent and 58 percent of the unshaded control. Results of the Tukey's multiple comparison indicated that there was no significant difference in seagrass density beneath the 5-ft and 4-ft platforms, but that both were significantly lower than the unshaded control (Figure 2).

There were significant differences in seagrass percent cover due to both season $(p=0.009)$ and shade $(\mathrm{p}<0.001)$. Seagrass percent cover at shaded sites was higher in May 2000 than in August 2000 (Figure 3). No interaction between season and shade was observed $(\mathrm{p}=0.214)$. Tukey's 


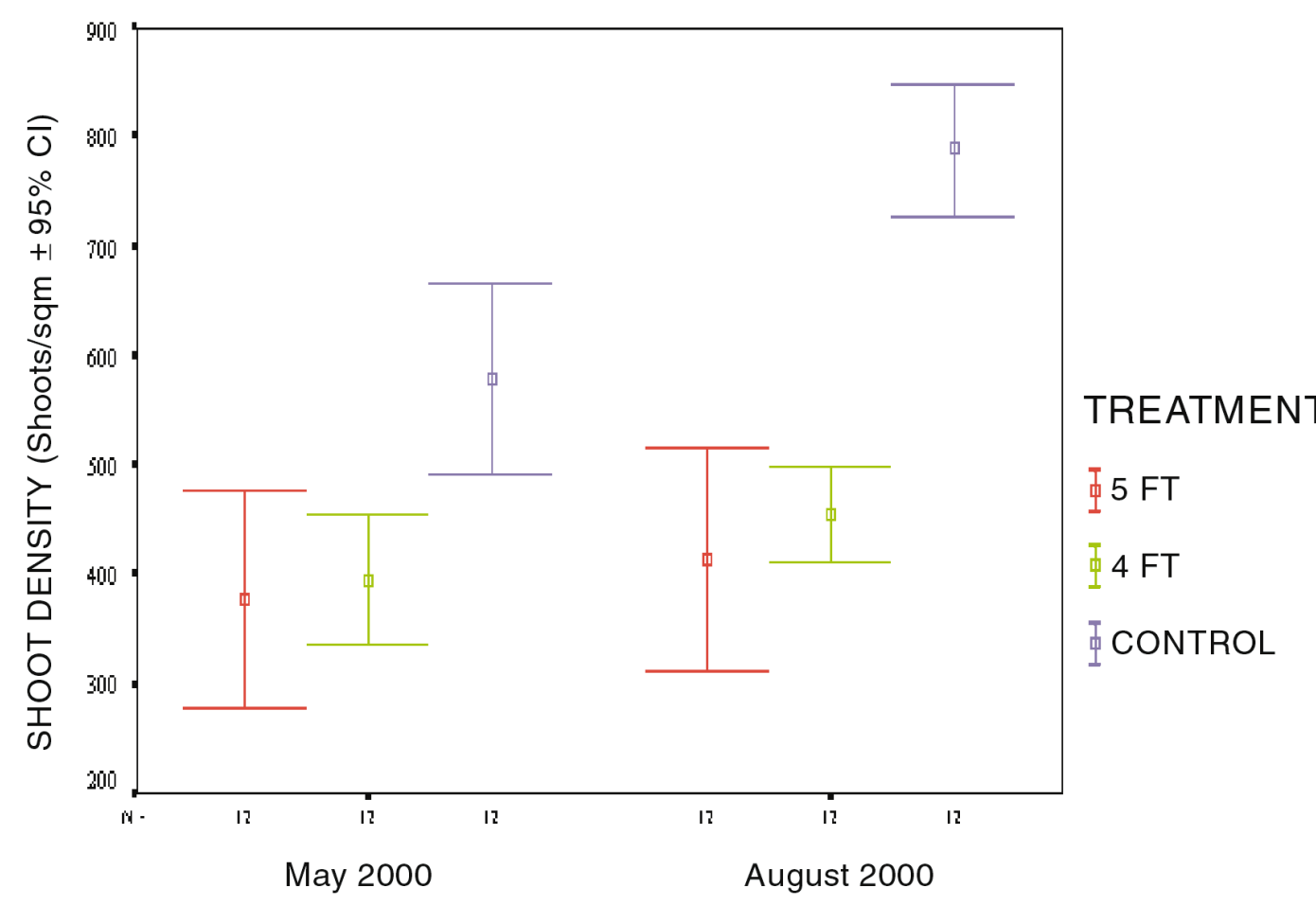

Figure 2. Comparison of shoot density between treatments at the beginning and end of the second growing season

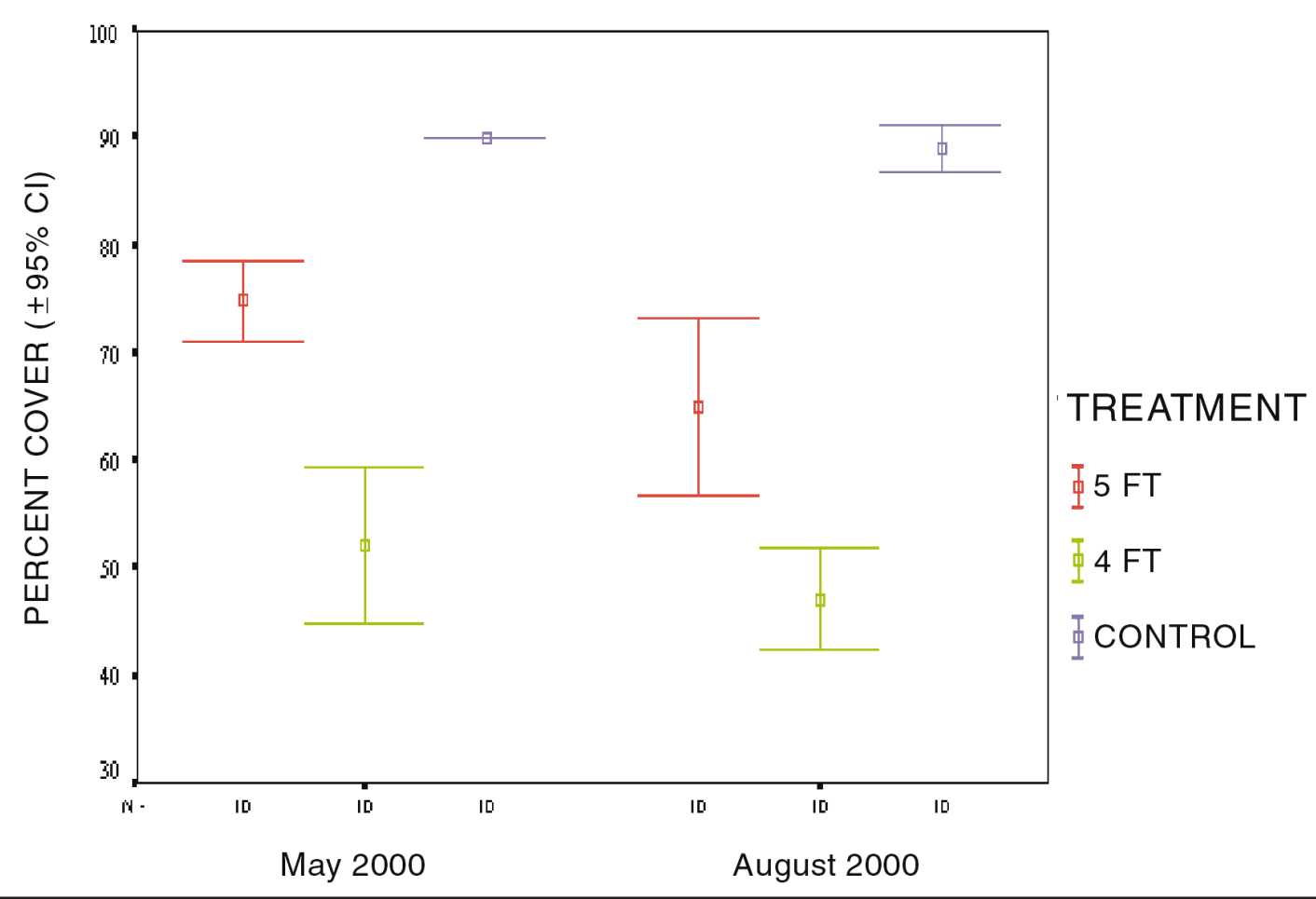

Figure 3. Comparison of percent cover between treatments at the beginning and end of the second growing season 
multiple comparison indicated that seagrass percent cover in each of the three treatments (5-ft platform, 4-ft platform, and control) was significantly different from the others.

Previous studies have suggested that irradiance levels of 13-14 percent SI represent a critical threshold for seagrass survival. When light levels are at or below this level, complete elimination of seagrass cover results (Molnar, Markley, and Mayo 1989; Czerny and Dunton 1995; Lee and Dunton 1997; Shafer 1999). If light levels beneath the docks exceed this level, seagrasses are able to survive at reduced density and biomass (Shafer 1999). For example, shoot density of Halodule wrightii beneath docks in Perdido Bay, AL, was reduced by 40-50 percent at light levels of 16-19 percent SI (Shafer 1999).

In this study, light levels under the grid platforms were between 53 percent and 61 percent of the unshaded control (Table 2). These values are consistent with the manufacturer's rating of 50 percent light transmittance for this material. Mean irradiance levels at the unshaded control site ranged from 32.8 percent SI to 42.6 percent SI, with an average of 38.1 percent SI (Table 2). Light levels beneath the experimental grating platforms in St. Andrew Bay, FL ranged from a minimum of 16.6 percent to 27.8 percent (Table 2). Mean irradiance level at the 5-ft platform was 23.3 percent SI; mean irradiance level at the 4-ft platform was 20.8 percent SI. These levels are well above the critical threshold value of 14 percent SI; therefore, seagrasses could be expected to persist indefinitely under these lighting conditions, although biomass and density will be reduced compared to unshaded conditions.

\begin{tabular}{|c|c|c|c|c|c|}
\hline \multirow[b]{2}{*}{ Date } & \multicolumn{3}{|c|}{ Mean Percent Surface Irradiance } & \multicolumn{2}{|c|}{ Mean Percent of Unshaded Control } \\
\hline & $5 \mathrm{ft}$ & $4 \mathrm{ft}$ & Control & $5 \mathrm{ft}$ & $4 \mathrm{ft}$ \\
\hline May 1999 & 16.6 & - & 33.4 & 49.7 & - \\
\hline May 2000 & 27.8 & 22.0 & 42.5 & 65.1 & 51.9 \\
\hline June 1999 & 20.8 & 22.3 & - & - & - \\
\hline June 2000 & 27.3 & 20.9 & 39.3 & 66.3 & 56.1 \\
\hline July 2000 & 25.8 & 21.1 & 42.6 & 59.5 & 50.3 \\
\hline August 2000 & 21.5 & 17.8 & 32.8 & 65.1 & 54.8 \\
\hline Average & 23.3 & 20.8 & 38.1 & 61.1 & 53.3 \\
\hline
\end{tabular}

Seagrass regrowth around pilings. Even in the absence of dock platforms, the presence of pilings can induce changes in seagrass communities due to baffling of currents, sediment deposition, scouring, attraction of bioturbators, and leaching from chemically treated wood (Beal, Schmitt, and Williams 1999). Bare areas or clearings around each individual pier piling represent another source of seagrass loss associated with dock construction. The size of these bare areas ranged from 35-78 in. in diameter for some docks in St. Andrew Bay, FL, even though the age of these docks varied widely. Due to the close spacing of the individual pilings, these bare areas were often observed to overlap and coalesce into continuous expanses of bare sediments in the area beneath the docks. The subsequent accumulation of oyster and other shell debris around the base of the piling may limit the ability of the seagrasses to recolonize this area. 
The method of piling installation used in this study reduces the physical removal and disturbance of the seagrasses. Measurements of the size of the bare areas surrounding each piling indicate that nearly complete regrowth of the seagrasses into the bare areas occurred within two growing seasons (Figures 4 and 5). One marine construction worker also noted that using the low pressure pump made the pilings steady faster, since less sand was disturbed. With the high-pressure pump, it was necessary to hold the piling in place longer and repack sand around the piling to steady it. ${ }^{1}$

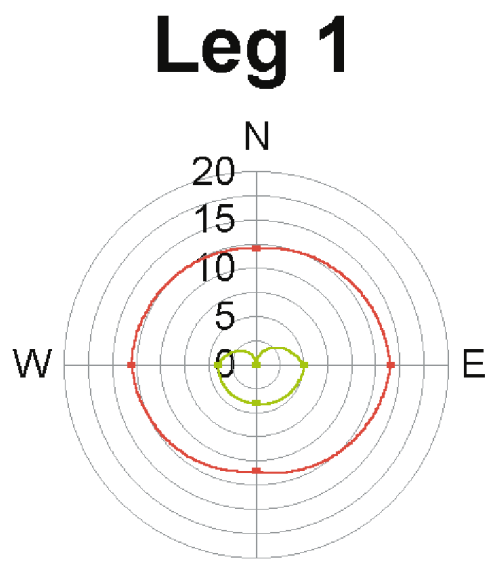

$S$

$\rightarrow$ Begin - End

$\operatorname{Leg} 3$

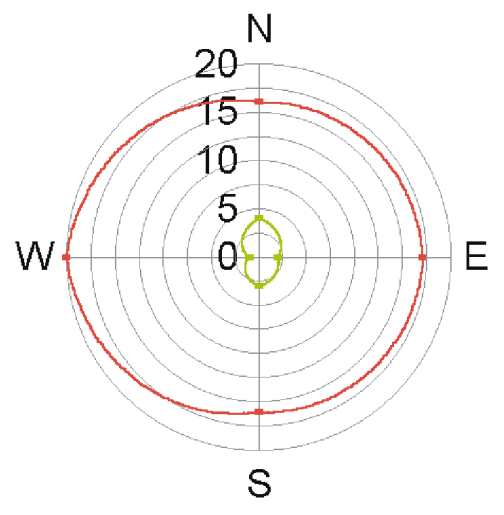

$\rightarrow$ Begin - End
Leg 2

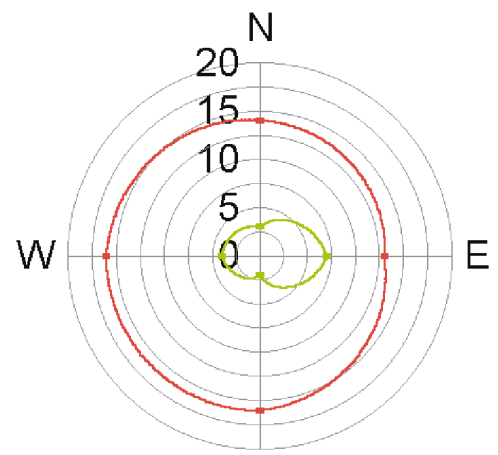

$S$

$=$ Begin - End

Leg 4

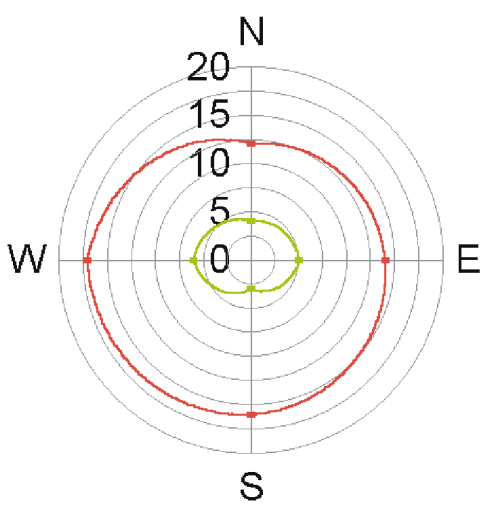

- Begin - End

Figure 4. Changes in size of clearing around each leg of 4-ft platform (units: inches)

1 Personal Communication, 1999, R. J. Gorman, Inc., Panama City, FL. 




$S$

$$
- \text { Begin }- \text { End }
$$

$\operatorname{Leg} 3$

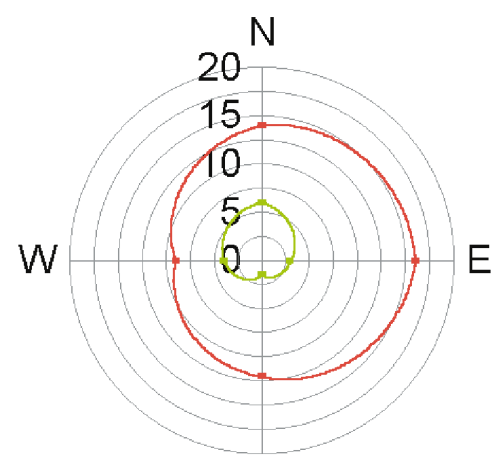

$S$

$=$ Begin $=$ End

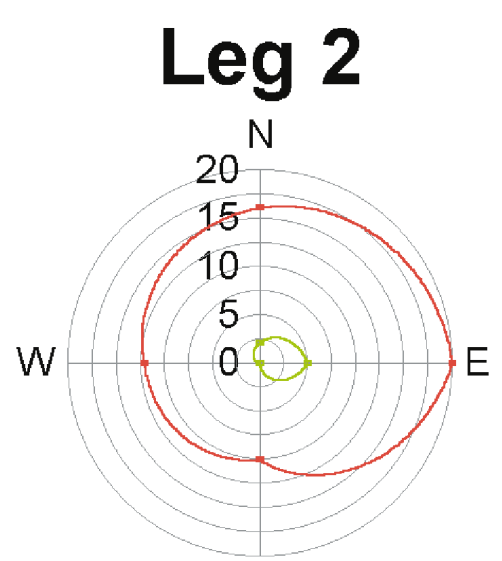

$S$

- Begin - End
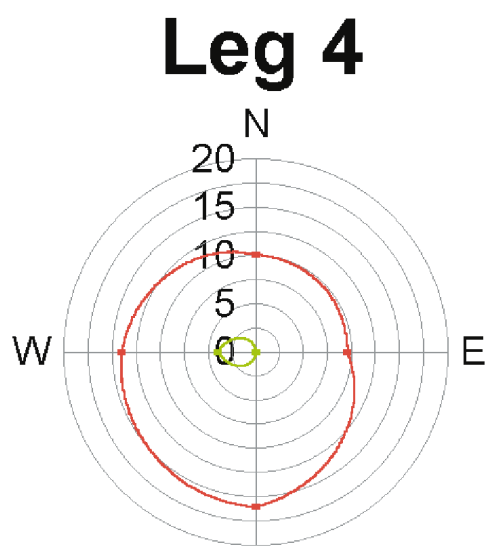

$S$

$\rightarrow$ Begin - End

Figure 5. Changes in size of clearing around each leg of 5-ft platform (units: inches)

Site inspections of other docks constructed using this method of piling installation confirm that a low-pressure pump results in little to no sand deposition around the pilings and the remaining seagrasses around the pilings looked healthy and had good growth around the piling. ${ }^{1}$ These results indicate that if used with care, this method of piling installation will reduce the area of seagrasses impacted compared to the alternative method of using a high-pressure jet pump.

Ecological implications. Loss of seagrass cover through shading, piling installation, or other means converts formerly vegetated areas of bay bottom into unvegetated areas. Total abundance and

1 Personal observation, 1999, J. Robinson, Fishery Biologist, National Marine Fisheries Service, Panama, FL. 
species richness of fishes is typically lower in unvegetated areas adjacent to seagrass (Bell and Pollard 1989; Connolly 1994). At the levels of shading produced by the fiberglass grating, seagrasses are not eliminated, but density and percent cover are reduced compared to adjacent unshaded areas.

The ecological significance of a reduction in total density or percent cover is difficult to assess. Numerous studies have observed that total abundance of organisms is greater in areas with greater structural complexity (higher density) (Adams 1976; Heck and Wetstone 1977; Orth and Heck 1980; Gore et al. 1981; Leber 1985; Bell and Westoby 1986a; Williams, Coen, and Stoelting 1990). This difference has been attributed to reduced predation and/or habitat selection. However, there is compelling evidence to suggest that over larger spatial scales, there is very little, if any, correlation between seagrass density and total abundance and species richness (Bell and Westoby 1986b; Worthington et al. 1992). Individual species may respond positively, negatively, or not at all, to reduced seagrass density (Bell and Westoby 1986a; Horinouchi and Sano 1999). Bell and Westoby (1986b) suggest that total abundance and species richness in seagrass beds are ultimately controlled by larval supply, and that larvae do not discriminate among beds based on density when they settle. Although individuals do not leave a bed soon after settlement, they may redistribute themselves within a bed to those areas with a micro-climate more favorable to survival (Bell and Westoby 1986b).

Economic considerations. The fiberglass grating possesses the strength and safety characteristics necessary for dock construction and is available from several different manufacturers in a variety of opening sizes and thicknesses. A cost comparison indicates that use of grating material may increase construction costs. In the St. Andrew Bay area, construction of a 4-ft by 8 -ft section of wooden deck, including materials and labor, is estimated to cost around $\$ 400$; a fiberglass grid section of the same size is estimated to cost around $\$ 800 .{ }^{1}$ Other studies report that costs may be comparable, since labor costs are greatly reduced for fiberglass grating dock construction (Beal, Schmit, and Williams 1999). Considerable savings could be achieved if only those sections of the dock or terminal platform directly over the seagrasses are built using the grating materials. Even if the initial cost for grating is higher, it may be more cost-effective in the long term because it requires no maintenance and the open grid is more likely to remain intact during the storm surge associated with hurricanes.

Summary and conclusions. Within the last few years, there has been a growing interest in the development of dock construction guidelines that will minimize the loss of seagrasses. In addition to the loss of seagrasses caused by shading, loss of seagrass cover occurs due to propellor scarring (Burdick and Short 1995; Loflin 1995) and piling installation. This study has demonstrated that: 1) the use of fiberglass grating to increase light transmission should reduce the amount of seagrass loss due to shading by docks and terminal platforms, and 2) the method of piling installation used in this study minimizes the physical destruction and removal of seagrasses, and resulted in nearly complete regrowth of the bare area by the end of the second growing season. Although total percent cover and density are reduced somewhat, the ecological consequences of this reduction in the small area beneath the docks are not likely to be significant. More importantly from an ecological

1 Personal Communication, 1999, R. J. Gorman, Inc., Panama City, FL. 
perspective, these alternative construction methods reduce patchiness and fragmentation of seagrasses, and contribute to maintaining the integrity of the seagrass beds.

ACKNOWLEDGMENTS: Completion of this project was made possible through the cooperative efforts of federal and state agency representatives and members of the private sector. Initial WRAP funding was provided by U.S. Army Corps of Engineers Headquarters, Regulatory Office. The construction of the experimental platforms was co-sponsored by the U.S. Army Engineer District, Jacksonville; U.S. Fish and Wildlife Service; and National Marine Fisheries Service. Three fiberglass grid panels used in construction of the experimental platforms were provided by ACR Process Equipment, Inc., in Lake Mary, FL. A local marine contractor (Bob Gorman, Inc.) donated time and labor for platform construction. Public awareness signs attached to each platform were produced at cost by the Bay County Board of County Commissioners.

ADDITIONAL INFORMATION: This information does not constitute an endorsement or advertisement for any particular provider and is provided as an example for use by those interested in obtaining these materials for dock construction. The fiberglass grate panels used in this study are manufactured by SeaSafe (Lafayette, LA; phone: 1-800-326-8842). Similar panels are manufactured by several other companies, including ChemGrate (1-800-527-4043). Panels are available in a variety of sizes and thicknesses. For safety, an anti-slip texture is integrally molded into the top surface. The manufacturer or local distributor should be consulted to ensure that the load-bearing capacity of the selected product is sufficient to support the intended purpose. Contact the manufacturer(s) for product specifications and a list of regional distributors.

POINTS OF CONTACT: For additional information, contact Deborah J. Shafer (601-634-3650, Deborah.J.Shafer@erdc.usace.army.mil), Engineer Research and Development Center, or the Program Manager of the Wetlands Regulatory Assistance Program, Dr. Russell F. Theriot (601634-2733, Russell.F.Theriot@erdc.usace.army.mil). This technical note should be cited as follows:

Shafer, D. J., and Robinson, J. (2001). "An evaluation of the use of grid platforms to minimize shading impacts to seagrasses," WRAP Technical Notes Collection (ERDC TN-WRAP-01-02), U.S. Army Engineer Research and Development Center, Vicksburg, MS. www.wes.army.mil/el/wrap

\section{REFERENCES}

Abal, E. G., Loneragan, N., Bowen, P., Perry, C., Udy, J., and Dennison, W. C. (1994). "Biological and morphological responses of the seagrass Zostera capricorni Aschers. to light intensity," Journal of Experimental Marine Biology and Ecology 178,113-129.

Adams, S. M. (1976). “The ecology of eelgrass Zostera marina (L.), fish communities. I. Structural analysis,” Journal of Experimental Marine Biology and Ecology 22, 269-291.

Beal, J. L., Schmit, B. S., and Williams, S. L. (1999). “The effects of dock height and alternative construction materials on light irradiance (PAR) and seagrass Halodule wrightii and Syringodium filiforme cover," Florida Dept. of Environmental Protection, Office of Coastal and Aquatic Managed Areas (CAMA). CAMA Notes.

Bell, J. D., and Pollard, J. D. (1989). “Ecology of fish assemblages and fisheries associated with seagrasses.” Biology of seagrasses, edited by A. W. D. Larkum, A. J. McComb, and S. A. Sheperd. Elsevier, Amsterdam, 536-564. 
Bell, J. D., and Westoby, M. (1986a). "Importance of local changes in leaf height and density to fish and decapods associated with seagrasses," Journal of Experimental Marine Biology and Ecology 104, 249-274.

Bell, J. D., and Westoby, M. (1986b). "Variation in seagrass height and density over a wide spatial scale: Effects on fish and decapods," Journal of Experimental Marine Biology and Ecology 104, 249-274.

Bulthuis, D. A. (1983). "Effects of in situ light reduction on density and growth of the seagrass Heterozostera tasmanica (Martens ex Aschers.) den Hartog in Western Port, Victoria, Australia," Journal of Experimental Marine Biology and Ecology 67, 91-103.

Burdick, D. M., and Short, F. T. (1999). "The effects of boat docks on eelgrass beds in coastal waters of Massachusetts," Environmental Management 23, 231-240.

Connolly, R. M. (1994). "Removal of seagrass canopy: Effects on small fish and their prey," Journal of Experimental Marine Biology and Ecology 184, 99-110.

Czerny, A. B., and Dunton, K. H. (1995). "The effects of in situ light reduction on the growth of two subtropical seagrasses, Thalassia testudinum and Halodule wrightii," Estuaries 18, 418-427.

Dennison, W. C. (1987). "Effects of light on seagrass photosynthesis, growth, and depth distribution," Aquatic Botany $27,15-26$.

Dunton, K. H. (1994). "Seasonal growth and biomass of the subtropical seagrass Halodule wrighti in relation to continuous measurements of underwater irradiance," Marine Biology 120, 479-489.

Fitzpatrick, J. R., and Kirkman, H. (1995). "Effects of prolonged shading stress on growth and survival of the seagrass Posidonia australis in Jervis Bay, New South Wales, Australia," Marine Ecology Progress Series 127, 279-289.

Gordon, D. M., Grey, K. A., Chase, S. C., and Simpson, C. J. (1994). "Changes to the structure and productivity of a Posidonia sinuosa meadow during and after imposed shading," Aquatic Botany 47, 265-275.

Gore, R. H., Gallaher, E. E., Scotto, L. E., and Wilson, K. A. (1981). "Studies on decapod crustacea from the Indian River region of Florida. XI. Community composition, structure, biomass, and species-areal relationships of seagrass and drift algae-associated macrocrustaceans," Estuarine, Coastal, and Shelf Science 12, 485-508.

Heck, K. L., Jr., and Wetstone, G. S. (1977). "Habitat complexity and invertebrate species richness and abundance in tropical seagrass meadows," Journal of Biogeography 4, 135-142.

Horinouchi, M., and Sano, M. (1999). "Effects of changes in seagrass shoot density and leaf height on abundances and distribution patterns of juveniles of three gobiid fishes in a Zostera marina bed," Marine Ecology Progress Series $183,87-94$.

Kenworthy, W. J., and Fonseca, M. S. (1996). "Light requirements of seagrasses Halodule wrightii and Syringodium filiforme derived from the relationship between diffuse light attenuation and maximum depth penetration," Estuaries 19(3), 740-750.

Leber, K. M. (1985). "The influence of predatory decapods, refuge, and microhabitat selection on seagrass communities," Ecology 66, 1951-1964.

Lee, K., and Dunton, K. H. (1997). "Effects of in situ light reduction on the maintenance, growth and partioning of carbon resources in Thalassia testudinum Banks ex König," Journal of Experimental Marine Biology and Ecology 210, 53-73.

Loflin, R. K. (1995). "The effects of docks on seagrass beds in the Charlotte Harbor Estuary," Florida Scientist 58, 198-205.

Molnar, G., Markley, S., and Mayo, K. (1989). "Avoiding and minimizing damage to Biscayne Bay seagrass communities from the construction of single family residential docks," DERM Technical Report 89-7, Metro Dade Dept. of Environmental Resources Management, Miami, FL.

Neverauskas, V. P. (1988). "Response of a Posidonia community to prolonged reduction in light," Aquatic Botany 31, 361-366.

Orth, R. J., and Heck, K. L., Jr. (1980). "Structural components of eelgrass (Zostera marina) meadows in the lower Chesapeake Bay-fishes," Estuaries 3, 278-288. 
Shafer, D. J. (1999). "The effects of dock shading on the seagrass Halodule wrightii in Perdido Bay, Alabama," Estuaries 22(4), 936-943.

Smith, K., and Mezich, R. (1999). "Comprehensive assessment of the effects of single family docks on seagrass in Palm Beach County, Florida," Draft Report for the Florida Fish and Wildlife Conservation Commission, Tallahassee, FL.

Williams, A. H., Coen, L. D., and Stoelting, M. S. (1990). Seasonal abundance, distribution, and habitat selection of juvenile Callinectes sapidus (Rathbun) in the northern Gulf of Mexico," Journal of Experimental Marine Biology and Ecology 137, 165-183.

Worthington, D. G., Ferrell, D. J., McNeill, S. E., and Bell, J. D. (1992). "Effects of the shoot density of seagrass on fish and decapods: Are correlations evident over larger spatial scales?" Marine Biology 112, 139-146.

Zar, J. H. (1996). Biostatistical Analysis. 3rd ed. Prentice Hall Inc., Upper Saddle River, NJ.

NOTE: The contents of this technical note are not to be used for advertising, publication, or promotional purposes. Citation of trade names does not constitute an official endorsement or approval of the use of such products. 


\section{APPENDIX A SUMMARY OF RECOMMENDATIONS FOR DOCK DESIGN AND CONSTRUCTION TO MINIMIZE SEAGRASS SHADING IMPACTS}

GENERAL RECOMMENDATIONS FOR DOCK DESIGN: Dock height, orientation, and width have been identified as the most important factors affecting the survival of seagrass under docks (Burdick and Short 1999). ${ }^{1}$ Although minor factors such as plank spacing may also affect light levels beneath the docks, a recent study suggests that plank spacing is of minimal importance. ${ }^{2}$ Species-specific differences in light requirements as well as environmental factors such as water clarity, water depth, and tidal range will also affect the ability of the plants to survive under docks. These factors should be considered in the development of guidelines to minimize dock shading impacts to seagrasses. Of these, dock height is the most critical. For fixed structures, height requirements are likely to vary from region to region depending on tidal range. Floating docks generally result in complete elimination of seagrass cover (Burdick and Short 1999), and should be avoided if possible. A north-south orientation provides a more favorable light environment for seagrass growth than an east-west orientation. Most docks are constructed perpendicular to shore, however, and property owners may have little choice concerning the orientation of the dock. Since the detrimental effects of poor orientation (east-west) may be at least partially offset by increased height (Burdick and Short 1999), higher minimum height requirements for docks oriented in an east-west direction could enhance seagrass survival. A narrow dock allows more light to be transmitted beneath the structure, particularly in the early morning and late afternoon hours. The construction of shared dock facilities would also reduce potential cumulative impacts from multiple dock structures. This concept could be promoted through the use of some type of incentives to property owners.

Using a combination of modeling and empirical data collected from several sites along the Massachusetts coast, the following recommendations for dock design were developed by Burdick and Short (1999). Docks less than $2 \mathrm{~m}$ wide, oriented within $10 \mathrm{deg}$ of north-south, and at least $3 \mathrm{~m}$ above the bottom will have the least impacts to seagrasses. An additional $0.4 \mathrm{~m}$ in height should be added for each additional meter increment in width. If the alignment is more than 10 deg from north-south, the dock should be $0.2 \mathrm{~m}$ higher for each additional 10-deg increment.

REGULATORY GUIDELINES FOR DOCK CONSTRUCTION: The following guidelines are presented as an example of dock construction guidelines currently in use in the northern Florida panhandle. These were developed for single-family residential docks by an interagency team composed of representatives from the U.S. Army Engineer District, Jacksonville; the National Marine Fisheries Service (Panama City, FL); the U.S. Fish and Wildlife Service (Panama City, FL); and the Florida Department of Environmental Protection, as well as members of the private sector marine construction industry. Technical assistance was provided by the U.S. Army Engineer Research and Development Center under WRAP Request Number 98-13. These guidelines were based on a literature review and limited field surveys in St. Andrew Bay and St. Joseph Bay, FL.

1 References cited herein are located at the end of the main text.

2 Unpublished data. (1998). Deborah Shafer, Research Marine Biologist, U.S. Army Engineer Research and Development Center, Vicksburg, MS. 
These guidelines are being considered for use statewide by the Jacksonville District Regulatory Division as part of the State General Permit. They could be adapted for use in other coastal areas where seagrasses may be impacted by dock construction.

1. Avoidance: The pier shall be aligned to minimize the size of the footprint over seagrass.

2. Orientation: Over seagrass portions of the dock or terminal, platform shall be oriented in a north-south orientation to the maximum extent that is practicable.

3. Pier height shall be a minimum of $5 \mathrm{ft}$ above MHW as measured from the top surface of the deck.

4. Pier width shall be a maximum of $4 \mathrm{ft}$. The pier may be constructed with railings. A turnaround area is allowed for piers greater than $200 \mathrm{ft}$ in length. The turnaround is limited to a section of the pier no more than $10 \mathrm{ft}$ in length and no more than $6 \mathrm{ft}$ in width. The turnaround shall be located at the midpoint of the length of the pier.

5. Pilings: The spacing of the pilings through seagrass shall be a minimum of $10 \mathrm{ft}$. They shall be installed in a manner that will not result in the formation of large rings of bare sediment around each pile. Any material deposited in seagrasses around the piling should be immediately removed.

6. Board Spacing: Gaps between deckboards shall be a minimum of 1/2 in.

7. Terminal Platforms: If possible, terminal platforms shall be placed in an area devoid of seagrass. This will avoid shading impacts as well as prop scarring.

a. Plank construction: The size of the platform shall be limited to $120 \mathrm{ft}^{2}$, not including catwalks. The configuration of the platform shall be a maximum of $6 \mathrm{ft}$ by $20 \mathrm{ft}$, of which a maximum 4-ft-wide by 20 -ft-long section shall conform to the 5 -ft height requirement. A narrow 2-ft section may be placed $3 \mathrm{ft}$ above $\mathrm{MHW}$ to facilitate boat access. The 2-ft section shall be cantilevered.

b. Grated deck construction: The size of the platform shall be limited to $160 \mathrm{ft}^{2}$, not including catwalks. The grated deck material must be approved by the Corps. The configuration of the platform shall be a maximum of $8 \mathrm{ft}$ by $20 \mathrm{ft}$, of which a maximum 5-ft-wide by 20-ft-long section shall conform to the 5-ft height requirement. A narrow 3-ft section may be placed $3 \mathrm{ft}$ above MHW to facilitate boat access.

8. Boatslips: A single, uncovered boatslip is allowed. A narrow catwalk (2-ft wide) may be added to facilitate boat maintenance along the outboard side of the boatslip and a 4-ft-wide walkway may be added along the stern end of the boatslip, provided all such walkways are elevated at least $5 \mathrm{ft}$ above MHW. The terminal end is designed to accommodate a boat lift, although the boat lift is not mandatory. The 2-ft-wide catwalk shall be cantilevered from the outboard mooring pilings (spaced no closer than $10 \mathrm{ft}$ apart). 